\title{
NUTRITIONAL INTAKE OF PEOPLE LIVING WITH HIV/AIDS (PLWHA) IN RURAL COMMUNITIES OF BENUE STATE, NIGERIA
}

\author{
*U. N AKWIWU \\ *Department of Agric Econonmics, Extension and Rural Development, Imo State University, \\ Owerri \\ *E-mail: uzoakwiwu@yahoo.co.uk
}

\begin{abstract}
Human Immunodeficiency Virus (HIV) among rural dwellers depletes quality of agricultural labour, productivity and reduces quality of life. Uptake of Antiretroviral Therapy (ART) has not significantly reduced consequences of infection, as the effort is being compromised by poor nutritional intake. This study analysed the nutritional intake of People Living with HIV/AIDS (PLWHA) in rural communities of Benue State, Nigeria. Data was collected from 190 PLWHA randomly selected from members of two rural support groups with high prevalence of HIV in Benue State using interview schedule. The data was analysed using descriptive statistics, Pearson product moment correlation and Chi Square at 0.05. Mean age of respondents was 37.5 $\pm 11.9,58.9 \%$ were females while majority had secondary school education (46.6\%). Diet diversity score $(4.1 \pm 1.3)$ was low among majority (64.7\%) of the respondents. Predominant food group consumed was tubers $(80.0 \%)$ and cereals (55.3\%). Iron (3.01) was the nutrient most consumed while vitamin B groups (1.15-1.60) were least consumed. However, age $(r=-0.15)$ and uptake of $A R T\left(\mathbf{X}^{2}=4.41\right)$ had significant relationship with nutritional intake. The study concluded that diet of PLWHA in Benue State was low in micronutrients, thus there is need for extension workers to be more pro-active in educating people living with HIV/AIDS in rural households on the need for good nutritional intake especially fruits and vegetables.
\end{abstract}

Keywords: People Living with HIV/AIDS, Diet diversity, Nutritional Intake

\section{https://dx.doi.org/10.4314/jafs.v16i2.8}

\section{INTRODUCTION}

Agriculture is far the most important sector of Nigeria's economy engaging about $70 \%$ of the labour force. The bulk of the people who engage in this sector are rural farmers who produce about $70 \%$ of food consumed in the country. Agricultural productivity however, anchors on the factors of production: land, capital, labour and entrepreneur (the farmer). Therefore, land use decrees, supply of agricultural inputs, loans, credits and subsidies in agriculture may contribute to achieving optimal productivity. The functionality of these factors, however, rests on the coordination of the entrepreneur, majority of who are rural farmers. Such coordination is influenced by their state of health. 
The rural populace have its enormous challenges perhaps as a result of their peculiar characteristics; poverty, low literacy level, high ratio of women to men, high level of fertility and isolation (Ekong, 2010). Of recent, HIV/AIDS a major killer disease has become an additional burden. In Benue state, known as the food basket of the nation, HIV prevalence rate was reported to be $12.7 \%$ (FMH, 2010). A major concern is a rural prevalence as high as $21.3 \%$ observed in some rural areas (FMH, 2010)

The impact of HIV/AIDS on agriculture is enormous; labour shortage, reduction in farm size, substitution of cash crops for crops which require less labour and strength to produce, poor household nutrition, food insecurity, economic losses among others. According to USAID (2001), for every $1 \%$ decrease in the supply of labour, production will decrease by $0.3 \%$. The World Health Organization also estimated that local losses in agricultural productivity from AIDS at the households or village level range from 10 to $15 \%$ in about ten sub-Saharan African countries, including Nigeria. Therefore, HIV goes beyond being a health issue as it has become more of a social and production issue.

HIV/AIDS is a disease which is transmitted from one individual to another through different means, but the most common is through hetero-sexual relationship and so it affects the productive age group who are mostly sexually active. Threat to the health and well being of this class of individuals within a rural community hinders productivity, depletes the availability and quality of farm labour and household food security. Agriculture and rural development may also suffer setback.

AIDS has no cure and may be managed through uptake of ART and adequate dietary intake. This is because HIV and nutrition are intimately linked (AVERT, 2010). As HIV infection increases in rural areas, critical questions are raised on how well drugs work if food is in short supply. Adequate dietary intake in resource poor environments and in most rural areas is a major challenge as food insecurity threatens proper nutritional intake. This is because consumption of a balanced diet in sufficient quantities has direct link to the three pillars of food security; availability, access and utilization. In most poor communities, food intakes are largely monotonous consisting of starchy staples. Arimond et al. (2009) observed that when grains or tuber based staple foods dominate and diet lacks vegetables, fruits and animal source foods, risk for a range of micronutrient deficiencies are high.

The understanding and practice of adequate nutrional intake among PLWHA is, therefore, an important step in the direction towards reducing the mortality rate from the pandemic and the consequent effect on agriculture and national economy as a whole. It is against this background that this study seeks to provide answers for the following research questions:

1. What are the respondents' personal and health-related lifestyle characteristics?

2. What is the level of adequacy of respondents' nutritional intake?

3. What are the constraints to respondents' adequate nutritional intake?

\section{Research Objectives}

The general objective of the study was to analyse the nutritional intake among People Living with HIV/AIDS Benue State. 
The specific objectives of the study were to:

1. determine the personal and health related lifestyle characteristics of PLWHA in rural communities of Benue State

2. determine the respondents' level of adequacy of nutritional intake

3. identify constraints to respondents' adequate nutritional intake

\section{Research Hypothesis}

The following null hypothesis was tested in the study:

$\mathrm{H}_{0} 1$ There is no significant relationship between personal and health-related lifestyle characteristics of PLWHA and the level of adequacy of their nutritional intake

\section{METHODOLOGY}

The study was conducted in Benue State of Nigeria. It lies at the middle-belt region of Nigeria with a population of $4,253,641$ (NPC, 2006). The state is administratively divided into three agricultural zones (A, B and C) and each zone has a government owned hospital were Anti Retroviral Therapy are administered to PLWHA. The major ethnic groups in Benue state are Tiv and Idoma. The present Benue state is endowed with agricultural produce such as yam, cassava, potatoes, rice, millet, guinea corn, groundnut, maize, beniseed, sesame, soya beans among others and a vast range of fruits and vegetables which all earned the state the slogan 'food basket of the nation'.

A multi stage sampling procedure was used to sample respondents for this study. The first stage was to purposively select two LGAs (Okpokwu and Tarka LGAs) to capture rural communities with high HIV prevalence in Benue State (FMH, 2014). In stage two, all HIV/AIDS support groups within the two LGAs were sampled comprising of one support group each in Okpokwu and Tarka of Benue State. Members of the support group are those who have tested and found to be infected with HIV. In stage three, list of all registered members of PLWHA in the support groups were obtained from the groups. Fifty percent of registered members in each group were sampled using simple random sampling technique. A total of 216 respondents were sampled for the study. Rate of return of questionnaire however was $88.38 \%$. Therefore, only 190 questionnaires were returned and were reported in this study. Interview schedule was used to collect quantitative data for the study.

Level of adequacy of dietary intake data was collected from respondents using the Individual Dietary Diversity Score (IDDS) adapted from FANTA scale (2007). Respondents were asked to tick Yes or No to the consumption of any of the options of 12 food groups given which are: carbohydrates, tubers, dark green leafy vegetables, fruits, meat, eggs, sea foods, food made from beans, yoghurt, milk or milk products, food made from oil, fat or butter, sugar or honey and beverages (alcoholic and non-alcoholic), using a 24 hours diet recall method. A 'yes' response was scored one and a 'no' response zero. The highest score was 12 while the lowest score was 0 . The higher the score, the more diversified the diet and the more adequate.

Nutrients intake of the respondents within twenty-four hours was determined by asking respondents to recall all food and beverages consumed and quantity taken the previous day using a food consumption questionnaire adopted from Food Consumption and Nutrition Survey questionnaire (2001) used by International Institute for Tropical Agriculture(IITA), United States Department of 
Agricultural Research Service (USDARS), United States Agency for International Development (USAID) and United Nations Childrens' Emergency Fund (UNICEF). Food samples were taken and weighed. Food consumed and weight was imputed into the Total Dietary Assessment (TDA) software to determine the actual nutrient intake of each individual and the level of adequacy. The mean score was computed and ranked.

Constraints to adequate dietary intake were measured by presenting to respondents, an array of possible constraints to adequate dietary intake. Respondents were asked to indicate the constraints they faced and the severity of the constraints. They were presented with a three-point scale of 'Not severe' which was scored zero, 'Severe' scored one and 'Very severe' two. The mean score was computed and ranked according to the order of severity from the most severe to the least severe.

Descriptive and inferential statistics were used to analyze the data. Descriptive statistics used include; mean, frequency and percentage distribution while inferential statistics used were Pearson Product Moment Correlation and Chi-square.

\section{RESULTS AND DISCUSSION}

\section{Respondent's personal characteristics}

Age distribution of respondents as presented on Table 1 shows that $27.4 \%$ were within the age range of 31-40 years with a mean age of 37.5 \pm 11.9 years. This suggests that the majority of the respondents were in their economically active and productive years. This is in agreement with Kormawa (2005) who opined that HIV/AIDS affects the most active and productive segment of the rural society. The prevalence of HIV/AIDS within this age group is an indication that agricultural productivity and inevitably food security may be threatened, thereby putting families increasingly at risk of food unavailability and poor nutritional intake in the study area.

More females $(58.9 \%)$ than males were infected with HIV. This is in agreement with AVERT (2016) report which states that HIV/AIDS prevalence rate were generally higher among females than males and that girls and women showed higher early vulnerability and infections than boys and men. These women account for $70 \%$ of the agricultural labour force and $80 \%$ of food production in Nigeria (Olomola, 2007) and preparing meals consumed in homes falls disproportionately on the women. This is a dangerous trend as the majority of women with HIV/AIDS implies threat to food security and poor nutritional intake by families.

The majority (51.1\%) of the respondents were married. According to UNAIDS (2012), the bulk of new infections occur in persons who are not engaging in high risk sex, a sub population that includes cohabiting or married partners. This is probably because the use of condom is low within this group. Infections acquired as a result of the previous or present high risk behaviours or relationship by one sex partner is easily transmitted to the unsuspecting partner. HIV infection within a family weakens family structure, reduces quality and quantity of agricultural labour. As a result of this, food production may reduce and food security becomes threatened.

The majority (53.2\%) had a household size of 5-8 with mean of $6.8 \pm 2.7$ members. Similarly the findings of Adebayo (2012) indicated average household size for most families to be between 5-8 members. The household is fairly large which may result in reduced food availability, reduced food intake and poor nutritional status. 
The highest educational level attained by most $(46.6 \%)$ of the respondents was secondary school education. This is consistent with the findings of Mofolorusho, Fatiregun and Osagbemi (2013) that most rural dwellers have at least a secondary school education.

Education plays a major role in information communication as it is necessary for proper processing of information as observed by Oladeji and Oyesola (2000). Therefore, knowledge on dietary intake is expected to be high, resulting in a positive attitude towards adequate dietary intake.

\section{Respondents' 24 Hours Diet and Nutrient Intake}

The distribution of respondents' 24 hours diet recall as presented on Table 2 a reveal that the majority $(80.0 \%)$ ate tubers, $(55.3 \%)$ of the respondents ate cereals, while dark green leafy vegetables and food made from beans were consumed by $54.2 \%$ and $55.3 \%$ of the respondents respectively. Food groups least consumed were food made from yoghurt, milk and milk products (4.2\%) and eggs (8.9\%). This result is consistent with the report of Sanusi (2010) on food group consumption pattern in Nigeria which reveals that consumption of cereals and tubers where consumed by a high percentage of people, while the consumption of milk and milk products and eggs were consumed by a few. Diets that are predominantly starchy staples are usually low in micronutrients which are needed to strengthen the body immune system.

This situation presents the urgent need for extension agents and stakeholders to promote the cultivation and consumption of food that give essential nutrients (fruits and vegetables) required for optimal health and the practice of animal husbandry in order to provide protein from animal sources. Apart from the high nutritive value of vegetables, they can also serve as means of providing additional income for households who produce them (Abugu et al, 2013)

\section{Categorization of respondents by dietary diversity score}

Dietary diversity measured by the number of food groups consumed. It reflects the concept that increasing the variety of food consumed in a diet helps to ensure that essential nutrients are consumed and promotes good health. (Wiesmann, Arimond and Cornelia, 2009)

The Individual Diet Diversity Score (IDDS) of the respondents as indicated on Table $2 \mathrm{~b}$ shows that the majority $(64.7 \%)$ of the respondents had low IDDS of various food group categories, while only $0.5 \%$ of the respondents had high IDDS of the food group category. The mean score was 4.1 for 12 food groups. This is an indication that respondents food intake is grossly inadequate. According to Bukusuba, Kikafunda and Whithead (2010), diet diversity reduced micro nutrient deficiencies and improves nutritional status. Therefore eating variety of foods from different groups is usually recommended.

The nutrient intake of the respondents as shown on Table $2 \mathrm{c}$ reveals that Iron (3.01) was the highest nutrient consumed. Protein (2.54) also ranked high in consumption next to Iron. The least consumed nutrient was vitamin B groups which are micronutrients. This is a result of low consumption of food which supplies the body with the much needed micronutrients for strong immune system. This is further elucidated by the findings on Table $2 \mathrm{a}$ which shows that eggs, milk and milk products as well as fruits were consumed by few respondents. Arimond et al. (2009) observed that individuals with high intake of starchy staples had diets with poorer micro-nutrient density. The general poor nutrient further validates the proposition that a low dietary diversity results in poor nutrient quality and adequacy. 


\section{Respondents' Constraint to Adequate Nutritional Intake}

Adequate nutritional intake is as much a needed component in the management of HIV even while taking ART. It slows down the progression of the virus and strengthens immune system. Poor income and low purchasing power in resource poor environment is a major contributory factor to poor nutritional intake as observed on Table 3 which shows that poor income (1.48) was ranked as the most severe constraint by the respondents. The findings of Banwat, Yakubu, Olalude and Ogunsakin (2013) on nutritional knowledge practice and status of HIV/AIDS patients in Jos corroborates this result.

There is no significant relationship between personal (age, sex, marital status, educational status, household size) and health-related lifestyle (taking ART and CD4 count) characteristics of PLWHA and adequacy of their nutritional intake.

There is significant correlation $(r=0.15, \mathrm{p} \unlhd 0.05)$ between the respondents' age and their nutritional intake adequacy. While taking ART had significant association $\left(\chi^{2}=4.41, \mathrm{p} \unlhd 0.05\right)$ with nutritional intake. It can, therefore, be inferred that a person's age may influence how well he eats. Also the uptake of ART may suppress attack on the immune system and aid appetite. Therefore, alongside uptake of ART, proper education on nutrition should be incorporated in treatment plan of PLWHA in rural communities of Benue State.

\section{CONCLUSION}

The nutritional intake of PLWHA in rural communities of Benue State accessed through 24 hours diet recall was low in micronutrients particularly of the vitamin B groups. Provision of food rich in micronutrients is very essential in managing HIV and preventing opportunistic infections. This could help rural dwellers living with HIV remain healthy and productive for a long time. Therefore, extension agents should encourage increase in the production and consumption of food rich in micronutrients among these group of people who are predominately farmers. This may be achieved through agricultural programmes and policies to increase commercial production of fruits and vegetables and ensure that extension workers are pro-active in combating the current challenge of HIV/AIDS among rural households threatening food security. 


\section{REFERENCES}

Abugu, R.O., Chah, J.M., Nwobodo C., Asadu, A.N., and Igbokwe E.M. (2013). Agricultural Extension Needs of Farmers in Telfairia Production and Marketing in Enugu State, Nigeria; Journal of Agricultural Extension Vol. 17(1) June, 2013: 49-59

Adebayo, O. O. (2012). Effects of family size on household food security in Osun State Nigeria. Asian Journal of Agriculture and Rural Development. 2 (2): 136-141.

Arimond M., Torheim L. E., Wiesmann D, Joseph M and Carriquiry A. (2009). Dietary Diversity as a measure of the micronutrient adequacy of Women's Diets: Results from Rural Banglesh site. Food and Nutrition Technical Assistance II Project (FANTA-2) www. Fanta Project.org. pg 25

Averting HIV/AIDS (AVERT) (2016). HIV/AIDS in Nigeria. Retrieved on April 132016 from Www.avert.org

Banwat M. E, Yakubu N. W., Olalude E. O. and Ogansakin J. A. (2013). An Assessment of the Nutritional knowledge, practice and status of Adult HIV/AIDS Patients attending an ART center is Jos, North Central Niger Health Care Curent Review. Journal of Food Science and Technology, 5(7): 156-162.

Bukusuba J. Kikafunda J. K. and Whihead R. G. (2010). Nutritional knowledge, attitude and practices of women living with HIV in Easter Uganda. Journal of Health population and Nutrition; 28 (2): 182-188.

Ekong E.E. (2010). An Introduction to Rural Sociology. Dove publishers 2010 3rd edition pg 43-47

Federal Ministry of Health (FMH) (2014). National HIV/Syphilis Sero-prevalence Sentinel Survey among pregnant women attending antenatal clinics in Nigeria. Abuja: National AIDS/STI Control Programme. 1-5.

Federal Ministry of Health (FMH) (2010). National HIV/AIDS Strategic Plan 2010-2015. Abuja Nigeria: Nigeria national Agency for the Control of AIDS, 2010

Kormawa, J.A. (2005). Impact of HIV/AIDS on African agriculture and role of the consultative group on Agricultural Research. Retrieved November 23, 2010 from www.warda.org/swiha/Dublin paper pdf p13.

Mofolorunsho K. G., Fatiregun A. A. and Osagbemi K. G. (2013). Socio Economic factors influencing the quality of life of People living with HIV/AIDS in Kogi State, Nigeria, International Journal of Tropical Medicine, 8 (1): 6-10,

Oladeji, J. O. and Oyesola, B. O. (2000). Information needs of rice farmers on harvesting and processing activities is Obafemi Owode Local Government Area of Osun State proceedings of the $6^{\text {th }}$ Annual Conference of Agricultural Extension Society of Nigeria (AESON), Ilorin T. A. Olowu Ed. 144-150.

Olomola A.S. (2007). Strategies for Managing the Opportunities and Challenges of the Current Agricultural Commodity Boom in sub Saharan Africa. In seminar papers on Managing 
Commodity Booms in sub Saharan Africa. A Publication of the AERC Senior Policy Seminar IX. African Economic Research Consortium (AERC), Nairobi Kenya.

Sanusi R.A. (2010). An assessment of dietary diversity in six Nigerian States. African Journal of Biomedical Research, 13 (3): 61-167

UNAIDS (2012). Report on Global Aids Epidemic. Retrieved April 13, 2018 from http://www.avert.org

USAID (2001). AIDS in Nigeria. A USAID brief. Retrieved Nov 20, 2008 from http:77www. aegis.com/files/synergyaids/Nigeria.pdf

Wiesmann D., Arimond M. and Cornelia L (2009). Dietary Diversity as a Measure of the Micronutrient Adequacy of Women's Diets. Results from Rural Mozambique Site. Food and Nutrition Technical Assistance II Project (FANTA 2) pg 2 
Table 1: Percentage distribution of respondents according to personal characteristics

\begin{tabular}{|c|c|c|}
\hline Variable & $\%$ & Mean \pm SD \\
\hline \multicolumn{3}{|l|}{ Age (years) } \\
\hline$\underline{20}$ & 5.8 & \\
\hline $21-30$ & 27.9 & \\
\hline $31-40$ & 27.4 & \\
\hline $41-50$ & 24.7 & \\
\hline $51-60$ & 10.5 & \\
\hline $61-70$ & 3.7 & $37.5 \pm 11.9$ \\
\hline \multicolumn{3}{|l|}{ Sex } \\
\hline Female & 41.1 & \\
\hline Male & 58.9 & \\
\hline \multicolumn{3}{|l|}{ Marital status } \\
\hline Single & 23.7 & \\
\hline Married & 51.1 & \\
\hline Divorced & 8.4 & \\
\hline Widowed & 16.8 & \\
\hline \multicolumn{3}{|l|}{ Household size } \\
\hline $1-4$ & 26.8 & \\
\hline $5-8$ & 53.2 & \\
\hline $9-12$ & 18.4 & \\
\hline 12 & 1.6 & $6.8 \pm 2.7$ \\
\hline \multicolumn{3}{|c|}{ Educational attainment } \\
\hline Non formal education & 5.3 & \\
\hline No formal education & 23.8 & \\
\hline Primary education & 12.7 & \\
\hline Secondary education & 46.6 & \\
\hline Tertiary education & 11.6 & \\
\hline
\end{tabular}

Source: Field survey data, 2015 
Journal of Agriculture and Food Sciences

U. N. Akwiwu

Volume 16 Number 2, October 2018 pp 88 - 99.

Table 2a: Percentage distribution of respondents based on 24 hours diet recall dietary intake

\begin{tabular}{ll}
\hline Food group & $\%$ \\
\hline Cereals (millet, wheat, sorghum, maize, bread, others) & 55.3 \\
Tubers (potatoes, yam, cassava, cocoyams, others) & 80.0 \\
$\begin{array}{l}\text { Dark green leafy vegetables (Ugu, green leaf, waterleaf, } \\
\text { bitter leaf, okro, others) }\end{array}$ & 54.2 \\
Fruits (mangoes, oranges, paw-paw, guava, others) & 41.6 \\
Meat (beef, pork, rabbit, chicken, offal, others & 28.4 \\
Egg & 8.9 \\
Sea foods (Fresh or dried fish, crayfish, shell fish) & 38.9 \\
Any food from beans & 55.3 \\
Any food from yoghurt, milk, other milk products & 4.2 \\
Any from made with oil fat or butter & 9.5 \\
Sugar or honey & 11.1 \\
Tea, coffee, cocoa, herbal drink & 6.3 \\
\hline
\end{tabular}

Source: Field survey data, 2015

Table 2b: Individual Dietary Diversity Score (IDDS)

\begin{tabular}{lll}
\hline IDDS & $\%$ & Mean \pm SD \\
\hline Low & 64.7 & \\
Average & 34.7 & $4.1 \pm 1.3$ \\
High & 0.5 & \\
\hline
\end{tabular}

Source: Field survey data, 2015 
Journal of Agriculture and Food Sciences

Volume 16 Number 2, October 2018 pp 88 - 99.

Table 2c Distribution of respondents' nutrient intake within 24 hours

\begin{tabular}{lll}
\hline Nutrients & Mean & Rank \\
\hline Calories & 1.87 & $4^{\text {th }}$ \\
Carbohydrates & 1.71 & $6^{\text {th }}$ \\
Protein & 2.31 & $3^{\text {rd }}$ \\
Dietary fibber & 1.11 & $12^{\text {th }}$ \\
Vitamin C & 1.31 & $5^{\text {th }}$ \\
Vitamin B1 & 1.42 & $7^{\text {th }}$ \\
Vitamin B2 & 1.29 & $10^{\text {th }}$ \\
Vitamin B3 & 1.32 & $7^{\text {th }}$ \\
Vitamin B6 & 1.19 & $11^{\text {th }}$ \\
Vitamin B12 & 1.33 & $9^{\text {th }}$ \\
Zinc & 2.27 & $2^{\text {nd }}$ \\
Iron & 3.01 & $1^{\text {st }}$ \\
\hline
\end{tabular}

Source: Field survey data, 2015

Table 3: Distribution of respondents by constraints to adequate dietary intake

\begin{tabular}{lll}
\hline Factors & Mean & Rank \\
\hline Poor appetite & 0.47 & $4^{\text {th }}$ \\
Change in taste of food & 0.38 & $6^{\text {th }}$ \\
Poor income & 1.23 & $1^{\text {st }}$ \\
Inadequate support from family members in preparing a & 0.49 & $3^{\text {rd }}$ \\
balanced diet & & \\
Lack of strength to work and tend their farms & 0.50 & $2^{\text {nd }}$ \\
Available resources are spent on medicine and health care & 0.35 & $7^{\text {th }}$ \\
Inadequate farming area & 0.19 & $10^{\text {th }}$ \\
I am being stigmatized & 0.39 & $5^{\text {th }}$ \\
I do not belong to any social group & 0.09 & $11^{\text {th }}$ \\
I have no information on good dietary intake & 0.21 & $8^{\text {th }}$ \\
To eat certain foods are forbidden (food taboos) & 0.26 & $9^{\text {th }}$ \\
\hline
\end{tabular}

Source: Field survey data, 2015

Journal of the Faculty of Agriculture and Veterinary Medicine, Imo State University Owerri website: www ajol.info 
Table 4: Chi Square and PPMC analysis of relationship between respondents' personal and health-related lifestyle characteristics and nutritional intake adequacy

\begin{tabular}{llllll}
\hline Variable & $\begin{array}{l}\text { Chi Square } \\
\text { Df }\end{array}$ & $\boldsymbol{\chi}^{2}$ value & p-value & $\begin{array}{l}\text { PPMC } \\
\text { r-value }\end{array}$ & p-value \\
\hline Age & & & 0.15 & $0.04^{*}$ \\
Household size & & & 0.01 & 0.19 \\
CD4 Count & & & 0.01 & 0.86 \\
Sex & 2 & 0.18 & 0.67 & & \\
Educational Status & 8 & 2.38 & 0.67 & & \\
Marital Status & 6 & 2.31 & 0.51 & & \\
Taking ART & 1 & 4.41 & $0.04^{*}$ & & \\
\hline
\end{tabular}

Source: Field survey data, 2015 